\title{
Introduction: Rooting the Study in the Theoretical Context
}

\begin{abstract}
Businesses face regulation, standards, and other external requirements from their operating environments. Taking the example of standards, the chapter reviews findings of these requirements' substantial impacts on innovation and new product development. Depending on the specific standard, these impacts can be positive (e.g. facilitating market access, defining interfaces to supporting infrastructures) or negative (e.g. causing lock-in). This makes standards a key topic for innovators to address. This chapter lays the theoretical foundation for the study by reviewing the limited existing literature on managing standards. Previous company-level studies of standards mostly do not address innovation contexts. Existing industry-level studies on innovation and standards provide few relevant insights for new product development contexts. The chapter concludes by outlining important theoretical gaps that the book addresses.
\end{abstract}

Keywords Innovation - Effects of standards on innovation - Managing standards in innovation - Standardisation - Impacts of standards

In their operations, businesses face regulation, standards, and other requirements from their operating environments. While some aspire to create free markets with as little external influence as possible (see Friedman, 1962; Krugman, 2007), others argue that such completely free markets are an illusion because they are embedded in societies that

(C) The Author(s) 2019

P. M. Wiegmann, Managing Innovation and Standards, https://doi.org/10.1007/978-3-030-01532-9_1 
impose limitations on actors' behaviour (Fligstein \& McAdam, 2012; Polanyi, 2001; Stiglitz, 2001). This implies that such requirements need to be carefully managed to ensure that businesses succeed within these boundaries. In this context, we want to understand how innovative companies manage standards-as an important example of such external requirements-while they are developing new products.

Standards have a profound impact on the development of new technologies, services, and other novel ideas. Extant literature finds that standards are often important factors supporting innovations but can also hinder in other cases. The arguably most fundamental positive effect is that standards often facilitate or even enable innovative products' and services' entry into the market. Other positive effects include, for example, the ability of standards to diffuse knowledge (e.g. Blind \& Gauch, 2009; Swann, 2010), standards' potential for facilitating collaboration (e.g. Allen \& Sriram, 2000), and their role in creating bandwagons for new technologies (e.g. Belleflamme, 2002; Farrell \& Saloner, 1985). On the other hand, examples for standards' negative effects include their potential to restrict creativity and the implementation of new ideas (e.g. Kondo, 2000; Tassey, 2000), as well as the danger that they lock users into using old technologies (e.g. Allen \& Sriram, 2000; Tassey, 2000).

These potentially far-reaching effects imply that innovators need to manage standards carefully so that they support, rather than hinder, innovation. Extant literature considers how standards can co-evolve with new technologies to facilitate their emergence (Blind \& Gauch, 2009; Featherston, Ho, Brévignon-Dodin, \& O’Sullivan, 2016; Ho \& O'Sullivan, 2017). These studies focus on the timing when specific types of standards are required to support a technology's further development and on technology roadmapping approaches that can help develop strategies for standardising new technologies. They therefore mostly look at new standards needed for an emerging technology and pay little attention to already existing standards that might affect an innovation and to the processes needed to develop and/or adapt standards for the innovation. This is an important limitation of the extant literature because many of the negative effects of standards found in literature, such as lock-in or limitations for creativity, arise in situations where an innovation is confronted with existing standards. Furthermore, these situations may be particularly challenging to manage because of the dynamics and resistance innovators are likely to encounter when challenging 
existing standards that may still serve the interests of other actors (see Wiegmann, de Vries, \& Blind, 2017).

To generate insights into how companies deal with both existing and new standards, we conduct an exploratory case study of a major innovation within an established industry where many standards apply. In this study, we take the perspective of innovating companies to understand how they manage this topic and its potentially important ramifications for their work. We study the micro Combined Heat and Power (mCHP) technology in the European heating industry. In this case, several companies developed new products in parallel, which were based on the mCHP technology. These products were aimed at existing markets where relevant standards already existed but only partly supported the new technology. Our study shows in detail how this innovation was affected by various standards. Our study also explores how these companies managed the relevant existing and new standards, which industry dynamics resulted from their activities and how these events impacted on the companies' new product development (NPD) activities.

Based on this in-depth study, we develop new theory about managing the co-evolution of innovation with standards and regulation. The resulting theoretical contributions are based on the fundamental finding that activities related to aligning an innovation with relevant standards and regulation occur on three nested levels: (1) the company, which is part of (2) an industry, which in turn is situated in (3) a wider context. Building on this insight, we identify company- and industry-level activities, which are needed to effectively use standards and regulation to align the innovation with needs and demands originating from the wider context. We also pinpoint supporting factors that are needed to carry out these activities successfully and establish through which channels events at each level impact on what happens on the other two levels. We therefore contribute a more detailed and dynamic view to the debate on how to manage standards in innovation contexts, both at company and industry levels.

To firmly root our study in previous findings, we provide a more detailed review of the literature that we summarised in the previous paragraphs. We first look into the extant findings on the links between standards and innovation (Sect. 1.1). Following this discussion, we consider existing insights on how standards can be managed in innovation contexts in Sect. 1.2, which culminates in identifying several important theoretical gaps that motivate the study. 


\subsection{STANDARDS' EFFECTS ON INNOVATION}

Standards, which according to de Vries's (1999, p. 15) definition specify "a limited set of solutions (...) to be used repeatedly", at first sight appear to oppose innovation which aims to create new solutions rather than reuse a limited set of existing ones. In their literature reviews, Dahl Andersen (2013) and Swann and Lambert (2017) found many different ways in which standards impact on innovation. Despite the intuitive expectation that standards are at odds with innovation, Dahl Andersen (2013) reports that around $60 \%$ of papers included in his review found a positive link between standards and innovation.

Standards can be distinguished according to their economic functions which include (1) specifying interfaces and providing compatibility; (2) defining minimum quality and safety requirements; (3) reducing variety; (4) disseminating information; and (5) defining measurements (Blind, 2004, 2017; Swann, 2010). Egyedi and Ortt (2017) provide a further refined classification, according to which all standards have the primary functions of ( 1 ) reducing variety and (2) providing information. They then identify secondary functions, according to which standards can be distinguished: (1) ensuring compatibility; (2) providing reference measures and defining measurement methods; (3) establishing classifications and (4) codifying behaviour protocols (Egyedi \& Ortt, 2017). The impacts of standards differ substantially, depending on which of these categories they fall into (Blind, 2004, 2017; Egyedi \& Ortt, 2017; Swann, 2010). Consequently, most of the literature that we cite below focuses on specific types of standards and their effects.

Standards can also be distinguished according to whether they are 'design based' (prescribing a particular specification) or 'performance based' (requiring a certain performance level without specifying how this should be achieved) (Tassey, 2000). Generally speaking, designbased standards are more often constraining for innovation whereas performance-based standards usually are more supporting for innovation (Tassey, 2000). This distinction is therefore similarly important to the distinction between the economic functions for understanding the effects of standards on innovation.

Effects of standards occur at all stages of innovation. They affect the incentives for companies to innovate (e.g. de Vries \& Verhagen, 2016; Maxwell, 1998); have implications for the technological development process (e.g. Allen \& Sriram, 2000; Blind \& Gauch, 2009); and 
Table 1.1 Overview of standards' potential effects on innovation

\begin{tabular}{|c|c|c|}
\hline Effects & Positive & Negative \\
\hline On NPD process & $\begin{array}{l}\text { - Providing information } \\
\text { - Specifying clear testing and } \\
\text { performance guidelines } \\
\text { - Facilitating collaboration and } \\
\text { division of labour }\end{array}$ & $\begin{array}{l}\text { - Limiting available options for } \\
\text { the technology's development } \\
\text { - Necessitating collaboration and } \\
\text { coordination between actors }\end{array}$ \\
\hline On diffusion & $\begin{array}{l}\text { - Providing legitimacy and market } \\
\text { access } \\
\text { - Supporting the emergence } \\
\text { of bandwagons and building } \\
\text { critical mass } \\
\text { - Providing opportunities for gen- } \\
\text { erating revenues from the inno- } \\
\text { vation through IPR licensing } \\
\text { - Supporting the creation and uti- } \\
\text { lisation of complementary assets } \\
\text { and supporting infrastructures }\end{array}$ & $\begin{array}{l}\text { - Preventing or hindering market } \\
\text { access } \\
\text { - Locking markets into obsolete } \\
\text { technologies }\end{array}$ \\
\hline
\end{tabular}

Source Author's summary of literature

influence the innovation's eventual diffusion in the market (e.g. Allen \& Sriram, 2000; Tassey, 2000). Since our research question concerns the management of standards in the NPD process, i.e. after the decision to innovate has been made, we are particularly interested in the effects of standards on the latter two phases. We provide an overview over these effects in Table 1.1 and outline them in more detail in Sects. 1.1.1 and 1.1.2.

\subsubsection{Standards' Effects on the New Product Development Process}

Standards play a key role in supporting the development of a new technology. They contribute to the institutional foundations between the involved actors and give them a common understanding of the technology (Bergholz, Weiss, \& Lee, 2006; Blind \& Gauch, 2009; Foray, 1998; Van de Ven, 1993). More concretely, three key effects of standardisation on NPD activities have been documented in the literature: (1) limiting options available to innovators; (2) acting as a source of information, including about performance requirements; and (3) facilitating (and sometimes requiring) collaboration and division of labour in innovation. 


\subsubsection{Standards Limiting Available Options}

The first (and most obvious) effect of standards is limiting the options that are available to an innovation's developers and restricting their choices and freedom in designing their product (e.g. Kondo, 2000; Tassey, 2000). Paradoxically, this may be positive in some situations because it can reduce the search costs involved in solving technological problems (Foray, 1998); ensure that different parties working on an innovation follow a common direction (Swann, 2010); and guide individual actors' investments (Van de Ven, 1993). Furthermore, the degree to which standards limit the available options differs depending on whether they are design- or performance based: While design-based standards are very restrictive, performance-based standards leave more freedom (Kondo, 2000; Tassey, 2000). Process standards that are written in this way may even increase creativity and motivation and thus lead to superior results (Kondo, 2000).

\subsubsection{Standards as an Information Source}

Second, standards are a useful source of information for innovation (Allen \& Sriram, 2000; Bergholz et al., 2006; Blind, 2004; Blind \& Gauch, 2009; Featherston et al., 2016; Schmidt \& Werle, 1998; Swann, 2010; Van de Ven, 1993). This information is particularly important when developing new technologies and/or products in networked industries where the innovation must work seamlessly with other elements of a network (Bergholz et al., 2006; Blind, 2004; Schmidt \& Werle, 1998). Standards can also be used to disseminate results from basic research to facilitate their application in an innovation (Allen \& Sriram, 2000; Bergholz et al., 2006; Blind \& Gauch, 2009) and can facilitate the interface between developing new products and developing the needed production processes to manufacture them at large scale (Lorenz, Raven, \& Blind, 2017). This also makes standards a potential external source of innovation for open innovation, in addition to the ones outlined by West and Bogers (2014).

Especially for design-based standards, the degree to which this information is useful for developing innovations depends on two factors. (1) Technological solutions included in standards are sometimes related to someone's intellectual property rights (IPR). If this is the case, this IPR must be available for licensing so that the information can be used by actors who are developing an innovation (Tassey, 2000). (2) The information disseminated through the standard should be up to date 
and have been included in the standard when the underlying technology was sufficiently mature. Outdated information may no longer be useful and even lock innovators into using old technological solutions (Allen \& Sriram, 2000; Swann, 2010; Tassey, 2000). Information included in standards that were passed too early in a technology's lifecycle may constrain its further development or be incomplete (Blind \& Gauch, 2009; Tassey, 2000).

When standards are performance based, the information included in them is valuable to innovators because it specifies targets that an innovation has to meet (Abraham \& Reed, 2002; de Vries \& Verhagen, 2016; Swann, 2010). However, when these requirements and testing procedures are not harmonised internationally, they can also lead to substantial additional efforts. In such cases, required tests need to be repeated for each country where the innovation is intended to be sold (Abraham \& Reed, 2002).

\subsubsection{Standards Facilitating Collaboration and Division of Labour}

Third, standards support and sometimes also require collaboration and division of labour in innovation. Standardised interfaces in complex system enable companies to focus their innovations on particular elements of these systems (Chen \& Liu, 2005; Tassey, 2000) and base these innovations on complementary assets provided by other parties (see, e.g. Teece, 1986, 2006). Furthermore, standardised interfaces between companies also facilitate collaboration between them in innovation projects, as Allen and Sriram (2000) demonstrate in the case of the Boeing 777's development. However, standards may also necessitate collaboration and a systemic approach to innovation when the requirements set in performance standards are higher than what one actor can achieve individually, as de Vries and Verhagen's (2016) case of the Dutch building sector shows. In such cases, achieving the required performance level may invoke reconfiguring a system's underlying architecture, rather than only innovating parts of it and therefore require the input of all actors who are involved in the system (de Vries \& Verhagen, 2016). From an innovator's point of view, this may signify substantial additional cost and effort.

\subsubsection{Standards' Effects on Technology Diffusion}

In addition to the effects on developing an innovation, standards also may enable or hinder the innovation's eventual success in the market. 
While they have the positive effect of providing legitimacy and access to the market and supporting the development of complementary assets, they potentially can also impede an innovation's diffusion by causing lock-in.

\subsubsection{Standards Providing Legitimacy, Market Access and Supporting Complementary Assets}

Standards are central to framing markets for technologies by defining and codifying rules, norms, and values that actors in these markets should follow (Delemarle, 2017). By doing so, they fulfil a key function of legitimising solutions (see Botzem \& Dobusch, 2012; Tamm Hallström \& Boström, 2010). This legitimation is likely to be particularly important for innovations where actors may be sceptical and still uncertain about the benefits. In such a context, testing the product according to respected standards can help signal an innovation's quality to the market (Tassey, 2000) and thus legitimise it. In Europe, such testing standards can also help to prove an innovation's regulatory compliance to the authorities and therefore provide access to the market. In technological areas that are covered by the 'New Approach', following standards which have been recognised by the European Commission gives actors a 'presumption of conformity' (Borraz, 2007; European Parliament \& Council of the European Union, 2002; Frankel \& Galland, 2017).

An additional way in which standards can contribute to an innovation's legitimacy is by signalling that it is likely to be adopted by many players (Farrell \& Saloner, 1985; Van de Ven, 1993). This expectation is based on the broad support needed for a solution to emerge as a standard (see Wiegmann et al., 2017) but also on other factors, such as the role that standards play in government procurement and the associated demand (Blind, 2008; Edler \& Georghiou, 2007; Rosen, Schnaars, \& Shani, 1988). Standards can therefore help to "build focus and critical mass in the formative stages of a market" (Swann, 2010, p. 9), prevent market fragmentation and support exploiting network effects (Bergek, Jacobsson, Carlsson, Lindmark, \& Rickne, 2008). If standards contribute to the widespread use of an innovation in this manner, this can also lead to substantial additional revenues for the innovation's developers from licensing fees paid on IPR that is declared standard essential (Kang \& Motohashi, 2015).

Finally, innovations often rely on complementary assets and/or supporting infrastructures for their success (Teece, 1986, 2006). In addition 
to creating critical mass which encourages others to supply these assets (Rosen et al., 1988), standards can also play a more direct role in their provision. By disseminating information about the innovation, standards help others to produce the required complementary assets in the manner outlined in Sect. 1.1.1 (Blind \& Gauch, 2009; Schmidt \& Werle, 1998). When standards are incorporated into the innovation's development in this manner, they also allow the innovation to make use of existing complementary assets and supporting infrastructures.

\subsubsection{Standards Causing Lock-In}

Although standards can contribute positively to an innovation's diffusion, they can also create lock-in that prevents users from adopting the new product (e.g. Allen \& Sriram, 2000; David, 1985; Farrell \& Klemperer, 2007; Tassey, 2000). A classic example of lock-in is the QWERTY keyboard which persists in usage despite better alternatives being available (e.g. Allen \& Sriram, 2000; David, 1985). In cases of lock-in, large parts of the market use a solution based on an outdated standard and face high switching costs (David, 1985; Rosen et al., 1988). These switching costs prevent the users from adopting the innovation, even if it is superior to the solution prescribed by the existing standard.

\subsection{Managing Standards in Innovation Contexts}

The effects of standards on innovation outlined in Sect. 1.1 make them an important element of innovation management. In Sect. 1.2.1, we summarise the limited available literature about company-level standards management. Other literature provides some insights into how standards and innovation co-evolve on the industry level (see Sect. 1.2.2) but neglects important dynamics, which may, e.g. result from conflicting stakes. In Sect. 1.2.3, we argue why these dynamics are likely to occur and what implications they may have for managing standards in innovation contexts. Finally, we summarise the important gaps in the literature that form the basis for our study (Sect. 1.2.4).

\subsubsection{Managing Standards on the Company Level}

Although literature about managing standards on the company level mostly does not specifically address innovation (the paper by Großmann, 
Filipović, \& Lazina, 2016 being a notable exception), several authors (Adolphi, 1997; Axelrod, Mitchell, Thomas, Bennett, \& Bruderer, 1995; Blind \& Mangelsdorf, 2016; Foukaki, 2017; Jakobs, 2017; van Wessel, 2010; Wakke, Blind, \& De Vries, 2015) offer insights that are also likely to apply in this context. On a fundamental level, they argue that managing standards needs to be aligned with the overall business strategy. To do so, companies should formulate a standardisation strategy (Adolphi, 1997; Großmann et al., 2016), which may be driven by the company's organisational culture (Foukaki, 2017). Based on this, organisational structures need to be put in place that enable activities on the tactical and operational levels which help achieve the strategic goals (Adolphi, 1997; Foukaki, 2017). The resulting organisational structures need to facilitate a number of day-to-day tasks, such as applying standards, monitoring the application of standards within the firm, informing company-internal stakeholders about standards, and influencing standard development processes (Adolphi, 1997). In the specific innovation context, Großmann et al. (2016) argue that these day-to-day tasks mainly concern screening existing standards regarding their relevance for the innovation and activities related to feeding the innovation's results into new standard development. These activities should then be related to specific decision points in the NPD process (Großmann et al., 2016).

Adolphi (1997) argues that companies face 'make-or-buy-decisions' whenever they encounter a situation where a standard is needed, meaning that they can either implement existing standards or contribute to developing new ones. ${ }^{1}$ Decisions to engage in standard development can be based on a number of strategic motives, such as facilitating market access, influencing regulation, seeking knowledge, maximising compatibility, or enhancing prospects in international trade (Axelrod et al., 1995; Blind \& Mangelsdorf, 2016; Foukaki, 2017; Jakobs, 2017; Wakke et al., 2015). Following this decision, companies need not only participate in forums where standards are developed but also carry out supporting activities, such as eliciting requirements and defining success criteria according to which the standardisation work's outcomes can be evaluated (Jakobs, 2017).

${ }^{1}$ Adolphi (1997) focuses on company-internal standardisation. Based on this background, he suggests a third option of developing company-internal standards. Due to our study's focus on the effects of (inter)national standards, we do not review this aspect of his work. 
Alternatively, companies can implement already-existing standards. Van Wessel (2010) identifies four necessary activities in this context, each of which needs to be carefully managed: (1) selecting appropriate standards, (2) implementing them, (3) using the standard, and (4) assessing the outcomes. One key aspect of managing these activities is that all affected company-internal stakeholders need to be involved throughout the process in order to ensure alignment with their needs (van Wessel, 2010).

\subsubsection{Co-evolving Innovation and Standards at Industry Level}

Because standards are key to framing markets for new innovations, they need to co-evolve with emerging technologies (Delemarle, 2017). Some existing studies consider how this (should) happen at the industry level (Blind \& Gauch, 2009; Featherston et al., 2016; Ho \& O'Sullivan, 2017). Blind and Gauch (2009) argue that specific types of standards (e.g. semantic standards or interface standards) are needed at various stages as a technology evolves from pure basic research to its application in the market. In this context, the interface between the $\mathrm{R} \& \mathrm{D}$ process and standardisation and the involvement of scientists and practitioners are particularly important to ensure that standards, reflecting both the state of research and practical applications, are developed (Blind \& Gauch, 2009). A technology roadmapping approach can be used to plan such a process and ensure that the necessary standards are developed at the right point in time (Featherston et al., 2016; Ho \& O'Sullivan, 2017). Featherston et al. (2016) and Ho and O'Sullivan (2017) develop a framework that links required standards to specific activities in the technological trajectory and allows actors to plan the standardisation process(es) alongside a technology's development.

These existing approaches to co-evolving standards and innovation at industry level focus on the development of new standards needed to support an innovation. While there are cases where scientific discoveries lead to an entirely new technology being developed with no pre-existing standards, such as the example of nanotechnology that Delemarle (2017) and Blind and Gauch (2009) use, many innovations are developed in areas where relevant standards already exist. If these standards have the positive effects on innovation cited in Sect. 1.1, this is not an issue. However, standards with negative effects such as lock-in, need to be updated to increase an innovation's chances of success. In this context, 
current literature offers some insights into how standards can be changed when needed.

Changes to standards occur on a regular basis-for example, $40 \%$ of the standards studied in a study of IT standards were subject to changes at some point in their lifecycles (Egyedi \& Heijnen, 2008; Schmidt \& Werle, 1998). Such an evolution of standards often follows out of innovations and is driven by four key reasons: (1) new user requirements; (2) anticipation of new technology features; (3) requirements from new technological development, and (4) new applications of existing technologies (Egyedi, 2008). These changes can manifest themselves in deviating ways of implementing the standard (Egyedi \& Blind, 2008) which implies that there is no formal process to change the standard and an alternative implementation may become a de facto standard if it is adopted by a large number of players (see, e.g. den Uijl, 2015). Furthermore, these changes can also result from more formalised, and therefore also more manageable, processes. Many standard setting organisations (SSOs) have procedures to update standards, e.g. by releasing updated versions and/or withdrawing outdated standards and replacing them with new documents (Egyedi \& Blind, 2008). Due to the time needed for these procedures, these changes in standards are likely to occur with some delay after the corresponding technological development (see Adolphi, 1997, p. 41).

\subsubsection{Dynamics Affecting the Management of Standards in Innovation Contexts}

Standardisation in innovation contexts often is a contentious issue. The standardisation process is likely to include a range of stakeholders and may also be influenced by external factors, such as societal debates and trends (Delemarle, 2017). When establishing new standards to support an innovation, these actors are likely to attempt influencing standards in a way that gives them an advantage in the innovation's further development (e.g. Blind \& Mangelsdorf, 2016; Delemarle, 2017; Rosen et al., 1988; Teece, 2006; Van de Ven, 1993). Furthermore, changing standards frequently leads to issues like added complexity, reduced interoperability, and problems for standard implementation (Egyedi \& Heijnen, 2008). Actors with no stake in the innovation may therefore resist changes in standards needed for the innovation's success to avoid such issues. 
Such competing interests have strong implications for a standardisation process, e.g. conflicts in SSOs (e.g. Jain, 2012), fierce battles in the market (e.g. den Uijl, 2015), or government involvement in the process (e.g. Meyer, 2012). The resulting dynamics may even be amplified when multiple of the three modes of standardisation (committee based; market based; government based) are involved (Wiegmann et al., 2017). This results in a challenge for innovators to influence standards in such a way that they are eventually supporting, rather than hindering.

\subsubsection{Gaps in the Literature}

The available literature provides a good foundation for understanding how to manage standards in innovation contexts, but nevertheless leaves important questions unanswered. Our literature review suggests that a more complete understanding is needed of (1) the company level, where the 'managing' is done, and (2) industry-level processes which are likely to result from these management activities but also shape them to some extent. The management of standards in innovation contexts is therefore preferably studied at both levels.

Specifically, we identify three gaps in the literature: (1) The literature on standards management at company level (see Sect. 1.2.1) mostly does not specifically address the context of innovation, even though we show in Sect. 1.1 that this is an area where the impacts of standards on companies' activities are particularly strong. On the other hand, the literature that considers how standards and innovation co-evolve (see Sect. 1.2.2) largely treats companies as 'black boxes' and does not consider the extensive activities that are likely to happen inside them. (2) Given the lack of attention to the company level, the literature on the co-evolution of innovation and standards also misses out on the dynamics within and between the company- and industry levels which we expect to be a major factor in this co-evolution. (3) Finally, the approaches to the co-evolution of standards in innovation contexts cited in Sect. 1.2.2 pay relatively little attention to conflicting interests and the resulting dynamics in the process (see Sect. 1.2.3). Because most innovative products are arguably aimed at existing markets with existing standards, and with actors who may oppose the innovation, such conflicts can be expected to often be critical when managing standards in this context.

These omissions motivate our case study. Our study design, as outlined in Chapter 2, allows us to capture activities on both levels of 
interest, the resulting dynamics and their effects on an innovation. We therefore contribute a first step towards addressing these three gaps in the literature.

\section{REFERENCES}

Abraham, J., \& Reed, T. (2002). Progress, innovation and regulatory science in drug-development: The politics of international standard-setting. Social Studies of Science, 32(3), 337-369. https://doi.org/10.1177/03063127020 32003001.

Adolphi, H. (1997). Strategische Konzepte zur Organisation der betrieblichen Standardisierung. Berlin, Vienna, Zürich: Beuth Verlag.

Allen, R. H., \& Sriram, R. D. (2000). The role of standards in innovation. Technological Forecasting and Social Change, 64(2-3), 171-181. https://doi. org/10.1016/S0040-1625(99)00104-3.

Axelrod, R., Mitchell, W., Thomas, R. E., Bennett, D. S., \& Bruderer, E. (1995). Coalition formation in standard-setting alliances. Management Science, 41(9), 1493-1508.

Belleflamme, P. (2002). Coordination on formal vs. de facto standards: A dynamic approach. European Journal of Political Economy, 18(1), 153-176. https://doi.org/10.1016/S0176-2680(01)00073-8.

Bergek, A., Jacobsson, S., Carlsson, B., Lindmark, S., \& Rickne, A. (2008). Analyzing the functional dynamics of technological innovation systems: A scheme of analysis. Research Policy, 37(3), 407-429. https://doi. org/10.1016/j.respol.2007.12.003.

Bergholz, W., Weiss, B., \& Lee, C. (2006). Benefits of standardization in the microelectronics industries and their implications on nanotechnology and other innovative industries. Retrieved August 14, 2017, from http://www.iec.ch/ about/globalreach/academia/pdf/bergholz-1.pdf.

Blind, K. (2004). The economics of standards-Theory, evidence, policy. Cheltenham: Edward Elgar.

Blind, K. (2008, September). Driving innovation-Standards and public procurement. ISO Focus, pp. 44-45.

Blind, K. (2017). The economic functions of standards in the innovation process. In R. Hawkins, K. Blind, \& R. Page (Eds.), Handbook of innovation and standards (pp. 38-62). Cheltenham: Edward Elgar. http://doi. org/ $10.4337 / 9781783470082$.

Blind, K., \& Gauch, S. (2009). Research and standardisation in nanotechnology: Evidence from Germany. The Journal of Technology Transfer, 34(3), 320-342. http://doi.org/10.1007/s10961-008-9089-8. 
Blind, K., \& Mangelsdorf, A. (2016). Motives to standardize: Empirical evidence from Germany. Technovation, 48-49, 13-24. https://doi.org/10.1016/j. technovation.2016.01.001.

Borraz, O. (2007). Governing standards: The rise of standardization processes in France and in the EU. Governance, 20(1), 57-84. https://doi. org/10.1111/j.1468-0491.2007.00344.x.

Botzem, S., \& Dobusch, L. (2012). Standardization cycles: A process perspective on the formation and diffusion of transnational standards. Organization Studies, 33(5-6), 737-762. https://doi.org/10.1177/0170840612443626.

Chen, K. M., \& Liu, R.-J. (2005). Interface strategies in modular product innovation. Technovation, 25(7), 771-782. https://doi.org/10.1016/j. technovation.2004.01.013.

Dahl Andersen, F. S. (2013). Standards and innovation: A systematic literature review. In K. Jakobs, H. J. de Vries, A. Ganesh, A. Gulasci, \& I. Soetert (Eds.), EURAS proceedings 2013-Standards: Boosting European competitiveness (pp. 77-91). Aachen: Wissenschaftsverlag Mainz.

David, P. A. (1985). Clio and the economics of QWERTY. The American Economic Review, 75(2), 332-337.

de Vries, H. J. (1999). Standardization-A business approach to the role of national standardization organizations. Boston, Dordrecht, and London: Kluwer Academic Publishers.

de Vries, H. J., \& Verhagen, W. P. (2016). Impact of changes in regulatory performance standards on innovation: A case of energy performance standards for newly-built houses. Technovation, 48-49, 56-68. https://doi. org/10.1016/j.technovation.2016.01.008.

Delemarle, A. (2017). Standardization and market framing: The case of nanotechnology. In R. Hawkins, K. Blind, \& R. Page (Eds.), Handbook of innovation and standards (pp. 353-373). Cheltenham: Edward Elgar. http://doi. org $/ 10.4337 / 9781783470082$.

den Uijl, S. (2015). The emergence of de-facto standards. Rotterdam: Erasmus Research Institute of Management (ERIM). Retrieved from http://hdl.handle.net $/ 1765 / 1$.

Edler, J., \& Georghiou, L. (2007). Public procurement and innovationResurrecting the demand side. Research Policy, 36(7), 949-963. https://doi. org/10.1016/j.respol.2007.03.003.

Egyedi, T. M. (2008). Conclusion. In T. M. Egyedi \& K. Blind (Eds.), The dynamics of standards (pp. 181-189). Cheltenham: Edward Elgar.

Egyedi, T. M., \& Blind, K. (2008). General introduction. In T. M. Egyedi \& K. Blind (Eds.), The dynamics of standards (pp. 1-14). Cheltenham: Edward Elgar. 
Egyedi, T. M., \& Heijnen, P. (2008). How stable are IT standards? In T. M. Egyedi \& K. Blind (Eds.), The dynamics of standards (pp. 137-154). Cheltenham: Edward Elgar.

Egyedi, T. M., \& Ortt, J. R. (2017). Towards a functional classification of standards for innovation research. In R. Hawkins, K. Blind, \& R. Page (Eds.), Handbook of innovation and standards (pp. 105-134). Cheltenham: Edward Elgar. http://doi.org/10.4337/9781783470082.

European Parliament, \& Council of the European Union. (2002, January 15). Directive 2001/95/EC of the European Parliament and of the Council on general product safety. Official Journal of the European Communities, L11, 4-17. Retrieved from http://eur-lex.europa.eu/LexUriServ/LexUriServ. do?uri=OJ:L:2002:011:0004:0017:en:PDF.

Farrell, J., \& Klemperer, P. (2007). Coordination and lock-in: Competition with switching costs and network effects. In M. Armstrong \& R. Porter (Eds.), Handbook of industrial organization (Vol. 3, pp. 1970-2056). Amsterdam: Elsevier B.V. http://doi.org/10.1016/S1573-448X(06)03031-7.

Farrell, J., \& Saloner, G. (1985). Standardization, compatibility, and innovation. The Rand Journal of Economics, 16(1), 70-83.

Featherston, C. R., Ho, J.-Y., Brévignon-Dodin, L., \& O’Sullivan, E. (2016). Mediating and catalysing innovation: A framework for anticipating the standardisation needs of emerging technologies. Technovation, 48-49, 25-40. https://doi.org/10.1016/j.technovation.2015.11.003.

Fligstein, N., \& McAdam, D. (2012). A theory of fields. New York: Oxford University Press.

Foray, D. (1998). Standards and innovation in technological dynamics. StandardView, 6(2), 81-84.

Foukaki, A. (2017). Corporate standardization management: A case study of the automotive industry. Lund: Lund University. Retrieved from http://portal.research. lu.se/ws/files/21522119/Corporate_Standardization_Management_A_Case_ Study_of_the_Automotive_Industry_Dissertation_2017.pdf.

Frankel, C., \& Galland, J.-P. (2017). Markets, standardization and innovation: Reflections on the European Single Market. In R. Hawkins, K. Blind, \& R. Page (Eds.), Handbook of innovation and standards (pp. 287-301). Cheltenham: Edward Elgar. http://doi.org/10.4337/9781783470082.

Friedman, M. (1962). Capitalism and freedom. Chicago: University of Chicago Press.

Großmann, A.-M., Filipović, E., \& Lazina, L. (2016). The strategic use of patents and standards for new product development knowledge transfer. RED Management, 46(2), 312-325. https://doi.org/10.1111/radm.12193.

Ho, J., \& O'Sullivan, E. (2017). Strategic standardisation of smart systems: A roadmapping process in support of innovation. Technological 
Forecasting and Social Change, 115, 301-312. https://doi.org/10.1016/j. techfore.2016.04.014.

Jain, S. (2012). Pragmatic agency in technology standards setting: The case of Ethernet. Research Policy, 4l(9), 1643-1654. https://doi.org/10.1016/j. respol.2012.03.025.

Jakobs, K. (2017). Corporate standardization management and innovation. In R. Hawkins, K. Blind, \& R. Page (Eds.), Handbook of innovation and standards (pp. 377-397). Cheltenham: Edward Elgar. http://doi. org/10.4337/9781783470082.

Kang, B., \& Motohashi, K. (2015). Essential intellectual property rights and inventors' involvement in standardization. Research Policy, 44(2), 483-492. https://doi.org/10.1016/j.respol.2014.10.012.

Kondo, Y. (2000). Innovation versus standardization. The TQM Magazine, 12(1), 6-10. Retrieved from http://www.emeraldinsight.com/journals. htm?articleid $=841925 \&$ show $=$ abstract.

Krugman, P. (2007). Who was Milton Friedman? New York Review of Books, $54(2)$, 27. Retrieved from http://givatram.org/bank/content/sikumim/3_2007_08243_08.pdf.

Lorenz, A., Raven, M., \& Blind, K. (2017). The role of standardization at the interface of product and process development in biotechnology. The Journal of Technology Transfer, 1-37. http://doi.org/10.1007/s10961-017-9644-2.

Maxwell, J. W. (1998). Minimum quality standards as a barrier to innovation. Economics Letters, 58(3), 355-360. https://doi.org/10.1016/ S0165-1765(97)00293-0.

Meyer, N. (2012). Public intervention in private rule making: The role of the European Commission in industry standardization. The London School of Economics and Political Science (LSE). Retrieved from http://etheses.lse. ac.uk/236/.

Polanyi, K. (2001). The great transformation-The political and economic origins of our time (2nd Beacon paperback). Boston, MA: Beacon Press.

Rosen, B. N., Schnaars, S. P., \& Shani, D. (1988). A comparison of approaches for setting standards for technological products. Journal of Product Innovation Management, 5(2), 129-139. https://doi. org/10.1016/0737-6782(88)90004-5.

Schmidt, S. K., \& Werle, R. (1998). Coordinating technology-Studies in the international standardization of telecommunications. Cambridge, MA: The MIT Press.

Stiglitz, J. E. (2001). Foreword. In K. Polanyi (Ed.), The great transformationThe political and economic origins of our time (2nd Beacon paperback, pp. viixvii). Boston, MA: Beacon Press. 
Swann, G. M. P. (2010). The economics of standardization: An update. Retrieved March 21, 2013, from http://www.bis.gov.uk/assets/biscore/ innovation/docs/e/10-1135-economics-of-standardization-update.pdf.

Swann, G. M. P., \& Lambert, R. (2017). Standards and innovation: A brief survey of empirical evidence and transmission mechanisms. In R. Hawkins, K. Blind, \& R. Page (Eds.), Handbook of innovation and standards (pp. 21-37). Cheltenham: Edward Elgar. http://doi.org/10.4337/9781783470082.

Tamm Hallström, K., \& Boström, M. (2010). Transnational multi-stakeholder standardization: Organizing fragile non-state authority. Cheltenham: Edward Elgar.

Tassey, G. (2000). Standardization in technology-based markets. Research Policy, 29(4-5), 587-602. https://doi.org/10.1016/S0048-7333(99)00091-8.

Teece, D. J. (1986). Profiting from technological innovation: Implications for integration, collaboration, licensing and public policy. Research Policy, 15(6), 285-305. https://doi.org/10.1016/0048-7333(86)90027-2.

Teece, D. J. (2006). Reflections on "Profiting from Innovation". Research Policy, 35(8), 1131-1146. https://doi.org/10.1016/j.respol.2006.09.009.

Van de Ven, A. H. (1993). A community perspective on the emergence of innovations. Journal of Engineering and Technology Management, 10(1-2), 23-51. https://doi.org/10.1016/0923-4748(93)90057-P.

van Wessel, R. (2010). Toward corporate IT standardization managementFrameworks and solutions. Hershey, PA: Information Science Reference.

Wakke, P., Blind, K., \& De Vries, H. J. (2015). Driving factors for service providers to participate in standardization: Insights from the Netherlands. Industry and Innovation, 22(4), 299-320. https://doi.org/10.1080/13662 716.2015 .1049865 .

West, J., \& Bogers, M. (2014). Leveraging external sources of innovation: A review of research on open innovation. Journal of Product Innovation Management, 31(4), 814-831. https://doi.org/10.1111/jpim.12125.

Wiegmann, P. M., de Vries, H. J., \& Blind, K. (2017). Multi-mode standardisation: A critical review and a research agenda. Research Policy, 46(8), 13701386. https://doi.org/10.1016/j.respol.2017.06.002. 
Open Access This chapter is licensed under the terms of the Creative Commons Attribution 4.0 International License (http://creativecommons.org/licenses/ by $/ 4.0 /$ ), which permits use, sharing, adaptation, distribution and reproduction in any medium or format, as long as you give appropriate credit to the original author(s) and the source, provide a link to the Creative Commons license and indicate if changes were made.

The images or other third party material in this chapter are included in the chapter's Creative Commons license, unless indicated otherwise in a credit line to the material. If material is not included in the chapter's Creative Commons license and your intended use is not permitted by statutory regulation or exceeds the permitted use, you will need to obtain permission directly from the copyright holder.

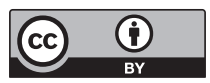

